\title{
A Pan-Precambrian Link Between Deglaciation and Environmental Oxidation
}

\author{
T. D. Raub and J. L. Kirschvink ${ }^{1}$
}

\begin{abstract}
Despite a continuous increase in solar luminosity to the present, Earth's glacial record appears to become more frequent, though less severe, over geological time. At least two of the three major Precambrian glacial intervals were exceptionally intense, with solid evidence for widespread sea ice on or near the equator, well within a "Snowball Earth" zone produced by ice-albedo runaway in energy-balance models. The end of the first unambiguously low-latitude glaciation, the early Paleoproterozoic Makganyene event, is associated intimately with the first solid evidence for global oxygenation, including the world's largest sedimentary manganese deposit. Subsequent low-latitude deglaciations during the Cryogenian interval of the Neoproterozoic Era are also associated with progressive oxidation, and these young Precambrian ice ages coincide with the time when basal animal phyla were diversifying. However, specifically testing hypotheses of cause and effect between Earth's Neoproterozoic biosphere and glaciation is complicated because large and rapid True Polar Wander events appear to punctuate Neoproterozoic time and may have episodically dominated earlier and later intervals as well, rendering geographic reconstruction and age correlation challenging except for an exceptionally well-defined global paleomagnetic database.
\end{abstract}

\section{INTRODUCTION}

Despite a 30 percent increase in solar luminosity during the past 4.6 billion years, we have solid geological evidence that liquid water was usually present on the surface. If the sun

${ }^{1}$ Division of Geological and Planetary Sciences, California Institute of Technology, Pasadena, CA 91125, USA. were to suddenly shift to even a 5-10 percent lower luminosity, our oceans would rapidly freeze over. We infer that this climatic regulation is due in large part to a combination of greenhouse gasses-principally $\mathrm{H}_{2} \mathrm{O}, \mathrm{CO}_{2}$, and $\mathrm{CH}_{4}$ - which have varied over time. For one of these, $\mathrm{CO}_{2}$, there is a clear inorganic feedback mechanism helping regulate climate (Walker et al., 1981), as $\mathrm{CO}_{2}$ removal by silicate weathering increases with temperature, a process that can act on a $10^{6}$ - to $10^{7}$-year timescale.

Geologists observe that a major shift in redox state of Earth's atmosphere happened sometime between 2.45 and $2.22 \mathrm{Ga}$ ago, as signaled by the loss of a mass-independent fractionation signal in sulfur isotopes, the disappearance of common detrital pyrite and uraninite from stream deposits, and the appearance of true continental redbeds, documented by a reworked paleosol that cements together coherent hematitic chips magnetized in random directions (Evans et al., 2001). The sedimentary sulfate minerals barite and gypsum also become more prevalent in evaporative environments post $2.3 \mathrm{Ga}$, as seen in the Barr River Formation of the Huronian Supergroup of Ontario (see Figure 1).

The reappearance of sedimentary sulfates after the Gowganda and Makganyene Glaciations at about 2.2 Ga follows a nearly 800 myr absence in the rock record (Huston and Logan, 2004), arguing that enough oxygen was then present in the atmosphere to oxidize pyrite to sulfate in quantities that sulfate-reducing organisms could not completely destroy.

Numerous hints in the rock record suggest a general relationship between changes in atmospheric redox state and severe glaciation. Most dramatically, the sedimentary package deposited immediately after the Paleoproterozoic low-latitude Makganyene glaciation in South Africa contains a banded iron formation-hosted manganese deposit that is the richest economic unit of this mineral known on Earth; Mn 
FIGURE 1 Gypsum casts, mud cracks, and ripples from the Barr River Formation north of Elliot Lake, Ontario, Canada.

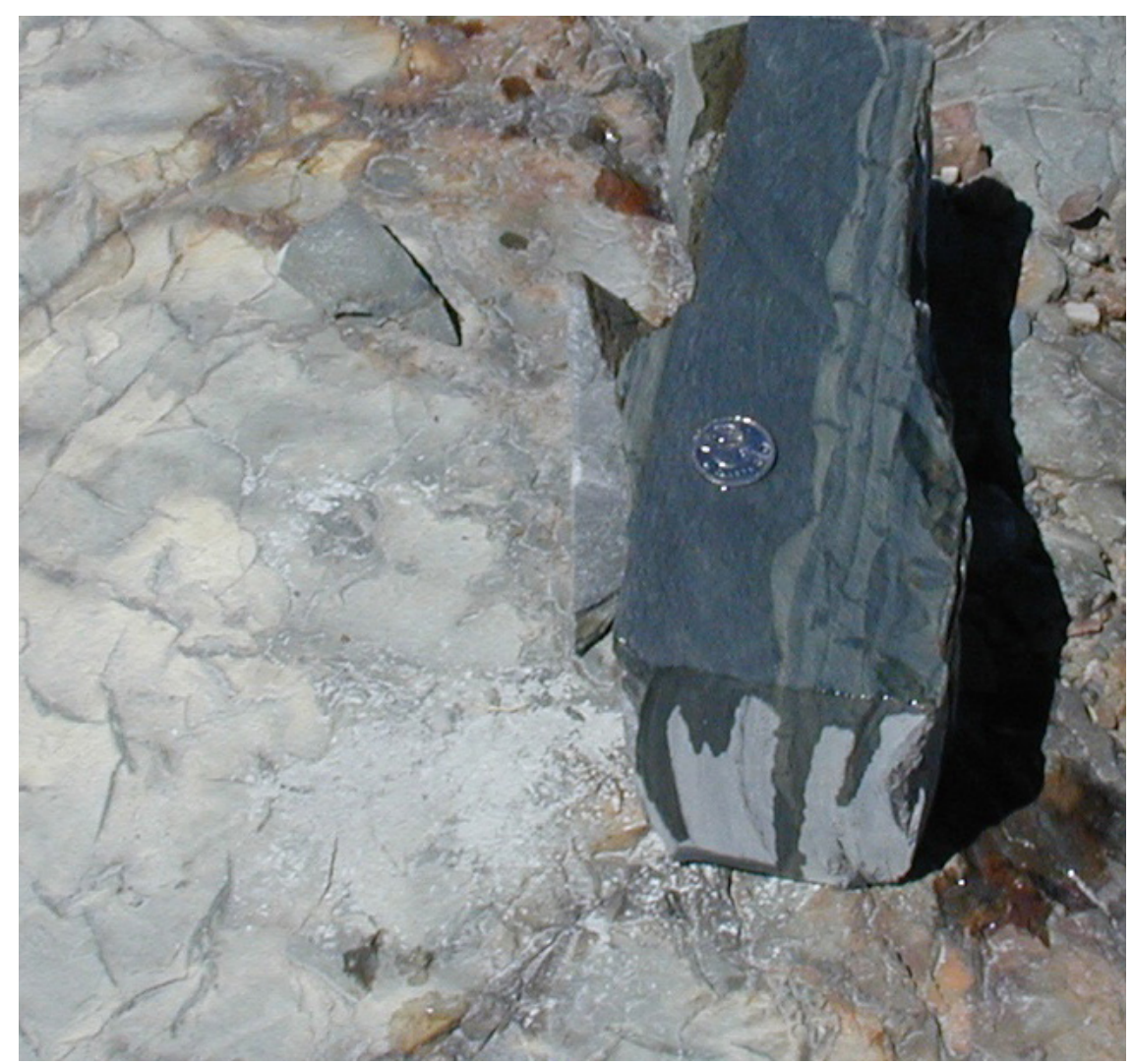

can only be precipitated from seawater by molecular oxygen (Kirschvink et al., 2000; Kopp et al., 2005). Similarly, Neoproterozoic glacial events are associated with apparent bursts of oxygenation and may have stimulated evolutionary innovations like the Ediacara fauna and the rise of Metazoa. We argue here that Precambrian glaciations are generally followed by fluctuations in apparent redox parameters, consistent with a postulate by Liang et al. (2006) that significant quantities of peroxide-generated oxidants are formed and released through glacial processes.

\section{LOW-LATITUDE GLACIATION AS A SNOWBALL EARTH}

Despite assertions to the contrary (Lovelock, 2006), climatic regulatory mechanisms have not always maintained large open areas of water on Earth's surface. Substantial evidence exists that large-scale continental ice sheets extended well into the tropics, yielding sea ice at the equator (Embleton and Williams, 1986; Evans et al., 1997; Sohl et al., 1999; Sumner et al., 1987). The deposition of banded iron oxide formations (BIFs) associated with glacial sediments implies both sealing off of air-sea exchange and curtailing the input of sulfate to the oceans, which otherwise would be reduced biologically to sulfide, raining out Fe as pyrite. The Snowball Earth hypothesis (Kirschvink, 1992) accounts for the peculiarities of low-latitude tillites, BIFs, abrupt and broadly synchronous glacial onset and termination, and many other features of these events (Evans, 2000; Hoffman, 2007; Hoffman and Schrag, 2002; Hoffman et al., 1998). No alternative hypothesis even attempts to explain as many diverse features of the Precambrian glacial record.

Initially, the most fundamental result driving the Snowball Earth hypothesis was a soft-sediment fold test on a varvite-like member of the $\sim 635$ Ma Marinoan-age Elatina formation in South Australia, which implied incursion of sea ice into subtropical latitudes (Figure 2) (Sumner et al., 1987). A few years later, Evans et al. (1997) demonstrated similarly robust results from the $\sim 2.22$ Ga Makganyene glaciation in South Africa, indicating that at least two intervals of geological time, separated by more than a billion years, experienced low-latitude glaciation. Comparison of less robust paleomagnetic data for all Precambrian glaciations with well-documented paleolatitudes for Phanerozoic glacial deposits yields an interesting schism. With the possible exception of the Archean Pongola event, there is a total absence of evidence for polar or subpolar glaciation throughout the Precambrian, while marine glacial sedimentation never breaches the tropics through the Phanerozoic (Evans, 2003). While the counterintuitive Precambrian polar glacial gap must be largely an artifact of the paleogeographic and 

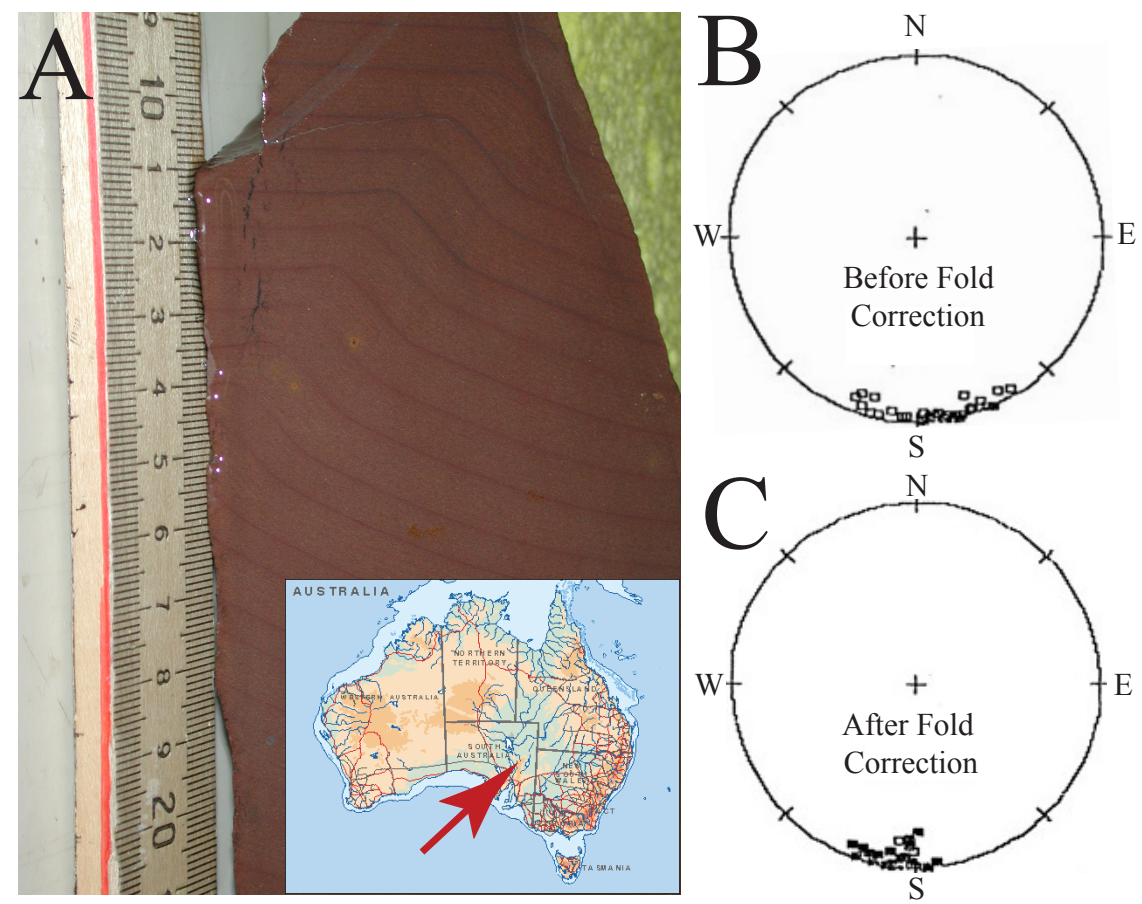

FIGURE 2 Soft-sediment paleomagnetic fold test on the rhythmite member of the Elatina Formation, Pichi-Richi Pass, Australia. The initial paleomagnetic study on this member by Embleton and Williams (1986) displayed a nearly equatorial remanent magnetization held in hematite, but lacked a geological field test to verify that the characteristic magnetization was acquired at or near the time of deposition. As part of the Precambrian Paleobiology Research Group (PPRG) at the University of California, Los Angeles, in 1986, Bruce Runnegar provided J. L. K. with an oriented block sample of this unit (Figure 2A), which displayed an apparent soft-sediment deformation feature. Careful subsampling and demagnetization of this block by then undergraduate student Dawn Sumner (now at the University of California, Davis) revealed a horizontally aligned, elliptical distribution of directions consistent with the earlier result (Figure 2B). However, correction for the bedding deformation significantly tightened the distribution, making it Fisherian and passing the McElhinny (1964) fold test at $\mathrm{P}$ $<0.05$. This result, along with an equally interesting result from a layer deformed by a glacial drop stone in the Rapitan Banded Iron Formation of Canada, was published as an American Geophysical Union abstract (Sumner et al., 1987); this led directly to the Snowball Earth Hypothesis (Kirschvink, 1992), and had the desired effect of stimulating further studies confirming the primary, low-latitude nature of the Elatina glacial event (Sohl et al., 1999; Williams et al., 1995).

rock preservation records (Evans, 2006), the data consensus points to an anomalously severe glacial mode in Proterozoic time relative to the Phanerozoic Era.

Evans (2003) suggests that this shift in Earth's glacial mode reflects the evolution of macroscopic continental life, especially of lichen and fungi through the EdiacaranCambrian transition (see also Peterson et al., 2005). Such organisms might modulate the silicate-weathering feedback to disfavor climate extremes, although the specifics of whether endolithic organisms promote or hinder physical and chemical weathering is surprisingly still ambiguous (see Beerling and Berner, 2005).

This fundamental Precambrian-Phanerozoic shift in Earth's glacial mode also appears to manifest itself in the relation of glacial events to a plate-tectonic supercontinent cycle. Figure 3 relates a simplified compilation of Earth's glacial record to a schematic representation of Earth's supercontinents through time. Whereas the Paleoproterozoic and Neoproterozoic low-paleolatitude glacial events occupied intervals dominated by dispersal of cratonic fragments from previous supercontinents (Kenorland and Rodinia, respectively), all Phanerozoic glacial events appear related to episodes of continental amalgamation. (Possible Ordovician glaciation could mark the formation of Gondwanaland; Carboniferous-Permian glaciation marks the assembly of Pangea; and the Miocene-present glacial epoch arguably presages the formation of a future supercontinent termed "SuperAsia" after the likely centroid of amalgamation.)

The characteristic length-scale of each supercontinent was centered at the "equator" and spread, as a yellow box, over the lifespan of that supercontinent. Blue waxing triangles indicate intervals of dominant supercontinent amalgamation, and red waning triangles indicate intervals of dominant supercontinent fragmentation and dispersal. A purple zone between the Paleoproterozoic supercontinent, Nuna, and the Mesoproterozoic-Neoproterozoic supercontinent, Rodinia, indicates basic uncertainty as to whether Nuna broke apart and reassembled into Rodinia, or whether 


\section{Supercontinents and Glaciations}

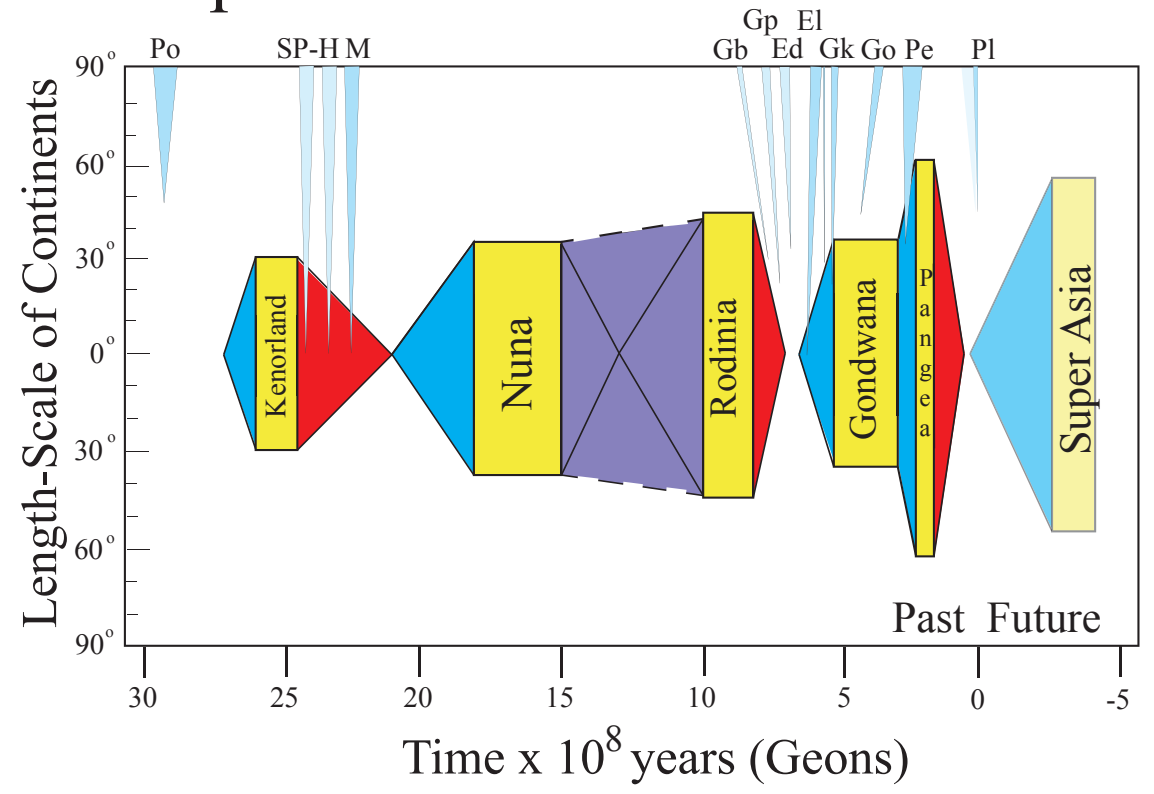

FIGURE 3 Character of glaciations and plate tectonics versus Earth history, measured in geons (100-million-year blocks of geological time). Surface areas for each of the demonstrated or likely supercontinents in Earth history were estimated, and a characteristic length scale for each supercontinent was defined as the square root of its surface area, converted from kilometers to degrees of arc. The vertical axis represents a characteristic meridian on Earth, running from 90 degrees north latitude to 90 degrees south.

a single supercontinent simply grew monotonically over that interval. The future supercontinent SuperAsia is predicted to begin its formal lifespan 250 million years from now, when the oceanic lithosphere at the edge of the Atlantic ocean will have reached a foundering density and produced subduction zones for enough time to reunite South America with southern Africa and North America with northern Africa and Eurasia. Presumably Australia will have long since crumpled a neo-Himalayan orogenic belt still higher between its northern margin and southeast Asia-eastern India.

Maximum equatorward extents of ice ages were estimated from the paleomagnetic database (dark icicle fill) or using artistic license (light icicle fill) where paleomagnetic data do not yet exist (e.g., for the Neoproterozoic Ghubrah event). An icicle was dropped from the North Pole to that maximum equatorward latitude, with thickness approximating a plausible duration for each glacial event. Precambrian glaciations are abbreviated as follows: $\mathrm{Po}=$ Pongola; $\mathrm{H}-\mathrm{SP}=$ Huronian and Snowy Pass Supergroups (at least two glaciations not correlative to South African Makganyene glaciation); $\mathrm{M}=$ Makganyene; $\mathrm{Gp}=$ Gariep; $\mathrm{Gb}=$ Ghubrah; $\mathrm{Ed}=$ Edwardsburg; El = Elatina-Ghaup; Gk = Gaskiers-Egan; Go $=$ Gondwana $; \mathrm{Pe}=$ Permian; $\mathrm{Pl}=$ Pleistocene.

Whereas Precambrian glaciations appear restricted to intervals of supercontinent fragmentation and dispersal, Phanerozoic glaciations appear more generally associated with supercontinent amalgamation and intervals of orogenesis. All glaciations are plausibly connected with minor or major episodes of environmental oxidation or atmospheric oxygenation.

For most of Phanerozoic time, an integrated geochemi- cal box model called GEOCARBSULF (Berner, 2006) predicts monotonic increases in atmospheric oxygen concentration spanning the late Ordovician, Carboniferous-Permian, and Miocene-present intervals of geologic time (for a recent discussion of the Paleozoic data, see Huey and Ward, 2005), with precipitous declines at the end-Permian. We suggest that a recent model for ice-based peroxide formation (Liang et al., 2006) contributes significantly to this Phanerozoic glaciation-oxygenation association, and extends even more significantly through the more severe Precambrian glacial episodes as well.

\section{PONGOLA: EARTH'S OLDEST KNOWN GLACIATION}

The middle Archean Pongola Supergroup exposed in Swaziland and parts of South Africa contains massive diamictite of the Klipwal and Mpatheni Members of the Delfkom Formation of the Mozaan Group (Young et al., 1998), which is constrained to be younger than underlying volcanics of the Nsuze group dated at $2985 \pm 1$ (Hegner et al., 1994) and older than a $2837 \pm 5$ Ma quartz porphyry sill (Gutzmer et al., 1999). The diamictites contain a diverse clast composition with striated and faceted pebbles, and occasional dropstones that attest to a glacial origin.

Although all sedimentary redox indicators throughout the Pongola Supergroup argue for widespread anoxia, studies of sulfur isotopes that indicate that mass-independent fractionation (MIF) decreases during and/or after the glacial intervals have been interpreted to support the presence of atmospheric oxygen (Bekker et al., 2005; Ohmoto et al., 2006). Although this is the conventional interpretation, senso 
stricto this is not required. The presence of significant MIF argues for $\mathrm{O}_{2}$ levels below that needed to form an ozone-UV shield, whereas the absence of MIF could indicate either a volcanic sulfur source or increased ocean and atmosphere mixing. In fact, before the studies were done, Kopp et al. (2005) predicted that a drop in sulfur MIF would be present in the Pongola sediments simply from increased ocean and atmosphere mixing expected for a time of glaciation compared with an ice-free world. Nonetheless, relative oxidation of the oceans that could also draw down atmospheric $\mathrm{SO}_{2}$ levels, even if unassociated with molecular oxygenation, remains a viable explanation for the geochemical blips associated with Pongola glaciation.

Nhelko (2004) studied the paleomagnetism of the Pongola diamictite and found an unusually strong and stable magnetization held in detrital magnetite, presumably derived from pulverizing basaltic-composition clasts present in the diamictite. He estimated the paleolatitude of deposition at $\sim 48^{\circ}$, with positive fold and conglomerate tests on the characteristic, two-polarity magnetization. As other Snowball Earth lithostratigraphic markers such as cap carbonates and carbonate clasts are generally absent, there is as yet no suggestion that Earth's oldest glaciation might have been a low-latitude, global event.

\section{PALEOPROTEROZIC GLACIAL INTERVALS}

At least three (and potentially many more) discrete intervals of glacial activity punctuate the geological record between about 2.45 and 2.22 Ga (e.g., Hambrey and Harland, 1981). Of these, the best-known and best-preserved belong to the Huronian Supergroup of Canada and the Transvaal Supergroup of southern Africa.

In Canada the classic Huronian succession includes the Ramsey Lake, Bruce, and Gowganda diamictites, separated from one another by thick successions of interbedded marine and fluvial sediments. A single carbonate unit (the Espanola formation) overlies the middle, Bruce Formation glacial horizon, with a gradual (not abrupt) transition from the diamictite to carbonate in the Elliot Lake region (abrupt transitions are seen elsewhere but could represent postglacial transgressions or unconformities). Basal volcanics have been $\mathrm{U}-\mathrm{Pb}$ dated at $\sim 2.45 \mathrm{Ga}$, and the entire glacial succession is cut by dikes and sills of the Nipissing swarm, providing an upper age constraint of $\sim 2.22 \mathrm{Ga}$. Sedimentary indicators of a generally reducing surface environment are common in and around the Ramsey Lake and Bruce diamictites, but the first appearance of continental redbeds appears just after the Gowganda event. This is either strong evidence for surface redox conditions reaching the ferrousferric transition, or else the evolution of terrestrial ironoxidizing organisms. As with the Archean Pongola event, MIF range of sulfur isotopes is diminished briefly after each glacial unit, hinting at but not proving transient oxidation events. Unfortunately, the paleolatitude of Huronian sedi- mentation is not known, as all paleomagnetic components identified so far have failed field stability tests (Hilburn et al., 2005).

Glaciogenic units in southern Africa's Transvaal Supergroup include the Duitschland, Timeball Hill, and Makganyene formations. Hannah et al. (2004) obtained a Re-Os pyrite isochron from the Timeball Hill Formation yielding an age of $2.32 \mathrm{Ga}$ for the unit, while Cornell et al. (1996) obtained a $\mathrm{Pb}-\mathrm{Pb}$ isochron indicating $\sim 2.22 \mathrm{Ga}$ for the age of Ongeluk Formation volcanics that interfinger with the top of the Makganyene diamictite. The youngest detrital zircons from thin sedimentary interbeds between flows of the Ongeluk volcanics are 2.23 Ga (Dorland, 2004), corroborating the $\mathrm{Pb}-\mathrm{Pb}$ isochron for the volcanics themselves. Paleomagnetic data from the Ongeluk volcanics indicate that the Makganyene is a low-latitude Snowball Earth event (Evans et al., 1997; Kirschvink et al., 2000). Sedimentary redox indicators in the Duitschland and most of the Timeball Hill imply reducing conditions, but the uppermost units of the Timeball Hill formation contain a hematitic oolitic unit, which if primary, hints again that the redox potential of the atmosphere and ocean system reached the ferrous/ferric transition (which is energetically only halfway between the hydrogen and oxygen redox potentials).

In Canada a paleosol at Ville St. Marie, Quebec (Rainbird et al., 1990) contains granule and pebble clasts with reddened rims at approximately the stratigraphic level of the Lorrain Formation. In South Africa the final pulse of the glaciogenic succession records ice-rafted dropstones in the basal units of the massive banded iron and sedimentary manganese in the Hotazel Formation. Together with the superjacent, randomly magnetized hematitic breccia paleosol (Evans et al., 2001) (see "Background"), there is unequivocal evidence for significant oceanic oxidation as well as atmospheric oxygenation in the immediate aftermath of low-paleolatitude Snowball Earth glaciation.

\section{STURTIAN AND MARINOAN}

After at least a 1-billion-year absence through late Paleoproterozoic time, all of the Mesoproterozoic Era, and the first half of the Neoproterozoic Era, BIFs reappear at $<720 \mathrm{Ma}$, intimately associated with early glacial deposits of the "Cryogenian" interval (Klein and Beukes, 1993). At least three discrete glaciations punctuate the latter half of Neoproterozoic time (Evans, 2000), and current correlation schemes appear to permit five or more distinct events. The older among these tend to be associated with hematite-enriched BIFs interrupting otherwise suboxic-to-anoxic, organicrich sediments, again suggesting penetration of oxidants to anomalous water depths accompanying deglaciation (Klein and Beukes, 1993).

The younger two of the Neoproterozoic deglaciations occupy the newly defined Ediacaran Period (Knoll et al., 2006), at its base ( 635 Ma, Condon et al., 2005; Hoffmann 
et al., 2004) and approximately its middle ( 580 Ma, Bowring et al., 2003). At $\sim 635$ Ma the basal Ediacaran "Marinoan" low-latitude event is only rarely associated with banded iron and sedimentary manganese formation (in Brazil's Urucum province), but it is frequently associated with reddened carbonate and shale dominating immediately postglacial sea-level transgression (e.g., Halverson et al., 2004).

Patterns of sulfur isotopic fractionation in carbonateassociated sulfate change across the Marinoan glaciation, such that seawater sulfate concentration was minimal during and after early Cryogenian glaciations, but significant following Marinoan glaciation (Hurtgen et al., 2005). Consistent with this trend, the postglacial transgressive sequences containing reddened carbonate and shale immediately after Marinoan deglaciation eventually culminate in black shale horizons with microbialaminate textures and isotopic signatures consistent with sulfate-reducing bacterial mat communities (e.g., Calver and Walter, 2000; Calver et al., 2004; see also Hoffman et al., 2007).

\section{MID-EDIACARAN EGAN/GASKIERS GLACIATION}

While the basal Ediacaran deglaciation marks the end of an unambiguously low latitude, likely Snowball Earth event, the middle interval of Ediacaran successions in northwest Australia and in Newfoundland is punctuated by a glacial event of uncertain severity. Correlation between the Egan glaciation in Australia's Ediacaran carbonate belt (Corkeron, 2007) and the Gaskiers glaciation in Newfoundland's Avalon terrane (Bowring et al., 2003) is not established, however both glacial events are younger than the Marinoan glaciation, and both are associated with anomalous carbonate facies in otherwise siliciclastic-dominated successions (Corkeron, 2007; Myrow and Kaufman, 1999).

As with the basal-Ediacaran Marinoan deglaciation, the mid-Ediacaran Gaskiers deglaciation is associated with postglacial reddening, culminating in pyrite-rich black shale at a presumed maximum flooding level. Silicate-hosted iron increases from pre-glacial to postglacial time, suggesting a step-function increase in atmospheric oxygen (Canfield et al., 2006).

Because the megascopic Ediacara fauna appear in the thick turbidite deposits following the Gaskiers deglaciation, back-of-the-envelope calculations suggest that the aftermath of the last Precambrian glaciation marked the first moment in Earth history when atmospheric oxygen levels exceeded $\sim 15$ percent of the present atmospheric level (Canfield et al., 2006). However, the Ediacara fauna have not yet been found in Newfoundland in the same, continuous stratigraphic section as the Gaskiers deglaciation, so the precise cause and effect of postglacial oxygenation and the evolution of complex life remains ambiguous.

\section{CORRELATION CAVEATS FOR EDIACARAN-CAMBRIAN EVENTS}

In a comprehensive study of inorganic and organic carbon, and sulfide as well as carbonate-associated-sulfate sulfur isotopes nearly spanning the Ediacaran Period, Fike et al. (2006) infer at least 25 million years of increasing bacterial sulfate reduction in the oceans following the Marinoan "Snowball" deglaciation. A sudden event known in Oman as the Shuram anomaly then quickly oxidized a previously isolated dissolved organic carbon reservoir, and the remainder of the Ediacaran Period experienced increasing levels of sulfur dissimilation reactions, permitted by enhanced oxygen concentrations (Fike et al., 2006).

Although the Shuram anomaly might correlate to the Gaskiers glacial event, in line with the general deglaciationoxygenation association sketched in this paper, its age is strictly underconstrained, with widely varying estimates (e.g., see Condon et al., 2005, and Le Guerroue et al., 2006). Because the Ediacaran Period is ubiquitously punctuated with paleomagnetic anomalies suggesting multiple, rapid true polar wander events (Evans, 1998; Evans, 2003; Raub et al., 2007) which might also oxidize vast quantities of organic carbon (Kirschvink and Raub, 2003; Raub et al., 2007), glaciations are not the only available and attractive correlation targets for major isotopic excursions. In fact, decreased generation time and increased frequency of mutation fixation accompanying niche isolation and global warming in the aftermath of rapid true polar wander bursts has been proposed as an explicit mechanism linking true polar wander to the evolution of Ediacara and Metazoa (Kirschvink and Raub, 2003). In that respect, even the direct link between the final Precambrian, "Gaskiers" deglaciation and the evolution of animal phyla must be regarded as still hypothesized more than proven.

\section{THE PEROXIDE PUMP: A MECHANISM FOR DEGLACIAL OXYGENATION}

Many glaciologists have noted a semiregular oscillation in the quantity of hydrogen peroxide contained in Antarctic and Greenland ice cores, with concentrations increasing dramatically during the interval of enhanced ozone hole due to anthropogenic emissions (Frey et al., 2005, 2006; Hutterli et al., 2001, 2004). Similar peroxide peaks are inferred for the polar regions of Mars and the ice sheet encasing Jupiter's moon, Europa (Carlson et al., 1999).

Liang et al. (2006) generalize the phenomenon of peroxide snow produced by photolysis of water vapor above a cold ice sheet and applied 1-D mass-continuity models of peroxide production to hypothetical glacial scenarios, including Snowball Earths.

With modern volcanic outgassing and dry adiabatic lapse rates, and at modern atmospheric pressure and UV inci- 
dence, a 10-million-year-long Snowball glacial event easily might rain out and capture in ice $\sim 0.1$ to 1.0 bar of molecular oxygen-equivalent hydrogen peroxide. The sensitivity of this astonishing result trends toward higher peroxide production for a depressed hydrologic cycle and lower global mean temperature, both plausible in a Snowball Earth scenario. UV-depletion of stratospheric ozone and enhanced molecular hydrogen escape to space (both correlated, among other factors, to decreased geomagnetic field intensity) would also increase peroxide mixing rates at Earth's surface.

We suggest that the model and mechanism of Liang et al. (2006) can explain a pan-Precambrian association in the geologic record of deglaciation with trace or significant environmental oxidation and, during the aftermath of at least the two most unambiguous Snowball Earth events, atmospheric oxygenation. We note that the Phanerozoic record of relative atmospheric oxygen concentration inferred by the GEOCARBSULF model is also consistent with monotonic oxygen production during and immediately following glaciation.

\section{ACKNOWLEDGMENTS}

T. D. R. was supported by a National Science Foundation Graduate Fellowship, and we gratefully acknowledge support from the Agouron Institute and the National Aeronautics and Space Administration Exobiology program.

\section{REFERENCES}

Beerling, D. J., and R. A. Berner. 2005. Feedbacks and the coevolution of plants and atmospheric CO2. Proceedings of the National Academy of Sciences U.S.A. 102(5):1302-1305.

Bekker, A., S. Ono, and D. Rumble. 2005. Low atmospheric $\mathrm{pO}_{2}$ in the aftermath of the oldest Paleoproterozoic glaciation. Astrobiology 5(2):244.

Berner, R. A. 2006. GEOCARBSULF: A combined model for Phanerozoic atmospheric $\mathrm{O}_{2}$ and $\mathrm{CO}_{2}$. Geochimica et Cosmochimica Acta 70(23):5653-5664.

Bowring, S., P. Myrow, E. Landing, and J. Ramezani. 2003. Geochronological constraints on terminal Neoproterozoic events and the rise of metazoans. Geophysical Research Abstracts 5:13219.

Calver, C. R., and M. R. Walter. 2000. The late Neoproterozoic Grassy Group of King Island, Tasmania: Correlation and palaeogeographic significance. Precambrian Research 100(1-3):299-312.

Calver, C. R., L. P. Black, J. L. Everard, and D. B. Seymour. 2004. U-Pb zircon age constraints on late Neoproterozoic glaciation in Tasmania. Geology 32(10):893-896.

Canfield, D. E., S. W. Poulton, and G. M. Narbonne. 2006. Late-Neoproterozoic deep-ocean oxygenation and the rise of animal life. Science 315(5808):92-95.

Carlson, R. W., M. S. Anderson, R. E. Johnson, W. D. Smythe, A. R. Hendrix, C. A. Barth, L. A. Soderblom, G. B. Hansen, T. B. McCord, J. B. Dalton, R. N. Clark, J. H. Shirley, A. C. Ocampo, and D. L. Matson. 1999. Hydrogen peroxide on the surface of Europa. Science 283(5410):2062-2064

Condon, D., M. Zhu, S. A. Bowring, W. Wang, A. Yang, and Y. Jin. 2005. $\mathrm{U}-\mathrm{Pb}$ ages from the neoproterozoic Doushantuo Formation, China. Science 308(5718):95-98.
Corkeron, M. 2007. "Cap carbonates" and Neoproterozoic glacigenic successions from the Kimberley region, north-west Australia. Sedimentology 54:871-903.

Cornell, D. H., S. S. Schutte, and B. L. Eglington. 1996. The Ongeluk basaltic andesite formation in Griqualand West, South-Africa-submarine alteration in a 2222 Ma Proterozoic sea. Precambrian Research 79(1-2):101-123.

Dorland, H. 2004. Provenance, Ages, and Timing of Sedimentation of Selected Neoarchean and Paleoproterozoic Successions on the Kaapvaal Craton. D.Phil. thesis. Rand Afrikaans University, Johannesburg.

Embleton, B. J. J., and G. E. Williams. 1986. Low paleolatitude of deposition for late Precambrian periglacial varvites in South Australiaimplications for Paleoclimatology. Earth and Planetary Science Letters 79(3-4):419-430.

Evans, D. A. 1998. True polar wander, a supercontinental legacy. Earth and Planetary Science Letters 157(1-2):1-8.

Evans, D. A. D. 2000. Stratigraphic, geochronological, and paleomagnetic constraints upon the Neoproterozoic climatic paradox. American Journal of Science 300:347-433.

Evans, D. A. D. 2003. A fundamental Precambrian-Phanerozoic shift in Earth's glacial style? Tectonophysics 375(1-4):353-385.

Evans, D. A. D. 2006. Proterozoic low orbital obliquity and axialdipolar geomagnetic field from evaporite palaeolatitudes. Nature 444(7115):51-55.

Evans, D. A., N. J. Beukes, and J. L. Kirschvink. 1997. Low-latitude glaciation in the Paleoproterozoic. Nature 386(6622):262-266.

Evans, D. A. D., J. Gutzmer, N. J. Beukes, and J. L. Kirschvink. 2001. Paleomagnetic constraints on ages of mineralization in the Kalahari manganese field, South Africa. Economic Geology 96:621-631.

Fike, D. A., J. P. Grotzinger, L. M. Pratt, and R. E. Summons. 2006. Oxidation of the Ediacaran Ocean. Nature 444(7120):744-747.

Frey, M. M., R. W. Stewart, J. R. McConnell, and R. C. Bales. 2005. Atmospheric hydroperoxides in West Antarctica: Links to stratospheric ozone and atmospheric oxidation capacity. Journal of Geophysical Research, Atmospheres 110(D23).

Frey, M. M., R. C. Bales, and J. R. McConnell. 2006. Climate sensitivity of the century-scale hydrogen peroxide $\left(\mathrm{H}_{2} \mathrm{O}_{2}\right)$ record preserved in 23 ice cores from West Antarctica. Journal of Geophysical Research, Atmospheres 111(D21301).

Gutzmer, J. N. Nhleko, N. J. Beukes, A. Pickard, and M. E. Barley. 1999. Geochemistry and ion microprobe (SHRIMP) age of a quartz porphyry sill in the Mozaan Group of the Pongola Supergroup: Implications for the Pongola and Witwatersrand supergroups. South African Journal of Geology 102(2):139-146.

Halverson, G. P., A. C. Maloof, and P. F. Hoffman. 2004. The Marinoan glaciation (Neoproterozoic) in northeast Svalbard. Basin Research 16(3):297-324.

Hambrey, M. J., and W. B. Harland. 1981. Earth's Pre-Pleistocene Glacial Record. Cambridge: Cambridge University Press.

Hannah, J. L., A. Bekker, H. J. Stein, R. J. Markey, and H. D. Holland. 2004. Primitive Os and $2316 \mathrm{Ma}$ age for marine shale: Implications for Paleoproterozoic glacial events and the rise of atmospheric oxygen. Earth and Planetary Science Letters 225(1-2):43-52.

Hegner, E., A. Kröner, and P. Hunt. 1994. A precise U-Pb zircon age for the Archean Pongola Supergroup volcanics in Swaziland. Journal of A frican Earth Sciences 18:339-341.

Hilburn, I. A., J. L. Kirschvink, E. Tajika, R. Tada, Y. Hamano, and S. Yamamoto. 2005. A negative fold test on the Lorrain Formation of the Huronian Supergroup: Uncertainty on the paleolatitude of the Paleoproterozoic Gowganda glaciation and implications for the great oxygenation event. Earth and Planetary Science Letters 232:315-332.

Hoffman, P. F. 2007. Comment on "Snowball Earth on Trial." EOS, Transactions of the American Geophysical Union 88(9):110.

Hoffman, P. F., and D. P. Schrag. 2002. The Snowball Earth hypothesis: Testing the limits of global change. Terra Nova 14(3):129-155. 
Hoffman, P. F., A. J. Kaufman, G. P. Halverson, and D. P. Schrag. 1998. A Neoproterozoic Snowball Earth. Science 281(5381):1342-1346.

Hoffman, P. F., G. P. Halverson, E. W. Domack, J. M. Husson, J. A.Higgins, and D. P. Schrag. 2007. Are basal Ediacaran (635 Ma) post-glacial "cap dolostones" diachronous? Earth and Planetary Science Letters 258(1-2):114-131.

Hoffmann, K. H., D. Condon, S. A. Bowring, and J. L. Crowley. 2004. U$\mathrm{Pb}$ zircon date from the Neoproterozoic Ghaub Formation, Namibia: Constraints on Marinoan glaciation. Geology 32(9):817-820.

Huey, R. B., and P. D. Ward. 2005. Hypoxia, global warming, and terrestrial Late Permian extinctions. Science 308:398-401.

Hurtgen, M. T., M. A. Arthur, and G. P. Halverson. 2005. Neoproterozoic sulfur isotopes, the evolution of microbial sulfur species, and the burial efficiency of sulfide as sedimentary pyrite. Geology 33(1):41-44.

Huston, D. L., and G. A. Logan. 2004. Barite, BIFs and bugs: Evidence for the evolution of the Earth's early hydrosphere. Earth and Planetary Science Letters 220(1-2):41-55.

Hutterli, M. A., J. R. McConnell, R. W. Stewart, H. W. Jacobi, and R. C. Bales. 2001. Impact of temperature-driven cycling of hydrogen peroxide $(\mathrm{H} 2 \mathrm{O} 2)$ between air and snow on the planetary boundary layer. Journal of Geophysical Research, Atmospheres 106(D14):15395-15404.

Hutterli, M. A., J. R. McConnell, G. Chen, R. C. Bales, D. D. Davis, and D. H. Lenschow. 2004. Formaldehyde and hydrogen peroxide in air, snow and interstitial air at South Pole. Atmospheric Environment 38(32):5439-5450.

Kirschvink, J. L. 1992. Late Proterozoic low-latitude global glaciation: The Snowball Earth. Section 2.3 in The Proterozoic Biosphere: A Multidisciplinary Study, eds. J. W. Schopf et al., pp. 51-52. Cambridge: Cambridge University Press.

Kirschvink, J. L., and T. D. Raub. 2003. A methane fuse for the Cambrian explosion: Carbon cycles and true polar wander. Comptes Rendus Geoscience 335(1):65-78.

Kirschvink, J. L., E. J. Gaidos, L. E. Bertani, N. J. Beukes, J. Gutzmer, L. N. Maepa, and R. E. Steinberger. 2000. Paleoproterozoic Snowball Earth: Extreme climatic and geochemical global change and its biological consequences. Proceedings of the National Academy of Sciences U.S.A. 97(4):1400-1405.

Klein, C., and N. J. Beukes. 1993. Sedimentology and geochemistry of the glaciogenic Late Proterozoic Rapitan iron-formation in Canada. Economic Geology and the Bulletin of the Society of Economic Geologists 88(3):542-565.

Knoll, A. H., M. R. Walter, G. M. Narbonne, and N. Christie-Blick. 2006. The Ediacaran Period: A new addition to the geologic time scale. Lethaia 39(1):13-30.

Kopp, R. E., J. L. Kirschvink, I. A. Hilburn, and C. Z. Nash. 2005. The paleoproterozoic snowball Earth: A climate disaster triggered by the evolution of oxygenic photosynthesis. Proceedings of the National Academy of Sciences U.S.A. 102:11131-11136.
Le Guerroue, E., P. A. Allen, A. Cozzi, J. L. Etienne, and M. Fanning. 2006. $50 \mathrm{Myr}$ recovery from the largest negative delta $\mathrm{C}-13$ excursion in the Ediacaran ocean. Terra Nova 18(2):147-153.

Liang, M. C., H. Hartman, R. E. Kopp, J. L. Kirschvink, and Y. L. Yung. 2006. Production of hydrogen peroxide in the atmosphere of a Snowball Earth and the origin of oxygenic photosynthesis. Proceedings of the National Academy of Sciences U.S.A. 103(50):18896-18899.

Lovelock, J. E. 2006. The Revenge of Gaia: Earth's Climate Crisis and the Fate of Humanity. New York: BasicBooks.

McElhinny, M. W. 1964. Statistical significance of the fold test in paleomagnetism. Geophysical Journal of the Royal Astronomical Society 8:338-340

Myrow, P. M., and A. J. Kaufman. 1999. A newly discovered cap carbonate above Varanger-age glacial deposits in Newfoundland, Canada. Journal of Sedimentary Research 69(3):784-793.

Nhelko, N. 2004. The Pongola Supergroup in Swaziland. D.Phil. thesis. Rand Afrikaans University, Johannesburg.

Ohmoto, H., Y. Watanabe, H. Ikemi, S. R. Poulson, and B. E. Taylor. 2006. Sulphur isotope evidence for an oxic Archaean atmosphere. Nature 442(7105):908-911.

Peterson, K. J., M. A. McPeek, and D. A. D. Evans. 2005. Tempo and mode of early animal evolution: Inferences from rocks, Hox, and molecular clocks. Paleobiology 31(2):36-55.

Rainbird, R. H., M. A. Hamilton, and G. M. Young. 1990. Formation and diagenesis of a sub-Huronian saprolith-comparison with a modern weathering profile. Journal of Geology 98(6):801-822.

Raub, T. D., J. L. Kirschvink, and D. A. D. Evans. 2007. True polar wander: Linking deep and shallow geodynamics to hydro- and bio-spheric hypotheses. In Treatise on Geophysics, vol. 5, ch. 14, eds. M. Kono and G. Schubert. Washington, D.C.: American Geophysical Union.

Sohl, L. E., D. V. Kent, and N. Christie-Blick. 1999. Paleomagnetic polarity reversals in Marinoan (ca $600 \mathrm{Ma}$ ) glacial deposits of Australia: Implications for the duration of low-latitude glaciation in neoproterozoic time. Geological Society of America Bulletin 111(8):1120-1139.

Sumner, D. Y., J. L. Kirschvink, and B. N. Runnegar. 1987. Soft-sediment paleomagnetic field tests of late Precambrian Glaciogenic Sediments. Transactions of the American Geophysical Union 68:1251.

Walker, J. C. G., P. B. Hays, and J. F. Kasting. 1981. A negative feedback mechanism for the long-term stabilization of Earth's surface temperature. Journal of Geophysical Research, Oceans and Atmospheres 86(NC10):9776-9782.

Williams, G. E., P. W. Schmidt, and B. J. J. Embleton. 1995. The Neoproterozoic (1000-540 Ma) Glacial Intervals-no more Snowball Earth. Comment. Earth and Planetary Science Letters 131(1-2):115-122.

Young, G. M., D. G. F. Young, C. M. Fredo, and H. W. Nesbitt. 1998. Earth's oldest reported glaciation: Physical and chemical evidence from the Archean Mozaan Group (similar to $2.9 \mathrm{Ga}$ ) of South Africa. Journal of Geology 106(5):523-538. 